\title{
Two Inbred Strains of Mice (SHN and SLN) with Different Mammary Tumorigenesis Established from the Same Basal Stock of Swiss Albino Mice
}

\author{
Hiroshi NAGASAWA \\ Pharmacology Division, National Cancer Center Research \\ Institute, Tsukiji 5-1-1, Chuo-Ku, Tokyo 104, Japan
}

(Received for publication : May 7, 1979)

\begin{abstract}
A basal stock of Swiss albino mice was selected to two ways for high and low mammary tumorigenesis and two new strains were established (SHN and SLN) $[27,34]$. They have still been selected and maintained by the strict brother $\times$ sister mating. SHN and SLN are now at F37 and F31, respectively.

In this paper, the changes in mammary tumorigenesis in both strains until F30 and the strain-difference in several characteristics concerning mammary tumorigenesis were briefly reviewed.

Mammary tumor incidence was increased and onset age of tumors was decreased with the advance of generation in SHN breeders and they were almost constantly 100\% and 6-7 months, respectively, after Fll. The effects of selection were not so marked in SLN breeders; mammary tumor incidence was fluctuate largely around the mean value of $\mathrm{P}$ generation and increased considerably after F23. The onset age of tumors became about 1 month later than $\mathrm{P}$ generation on average (Fig. 1).

SHN virgins showed mammary tumor incidence of more than $90 \%$ and the onset age of 8-9 months. The effect of selection in SLN females was marked in virgins and the incidence and the onset age were $10-20 \%$ and $14-18$ months, respectively, in each generation (Fig. 2).

While the life spans of breeders and virgins which died without mammary tumors were 8-14 months and 13-19 months, respectively, in both strains, the variations were so large in each generation.

All mammary tumors checked were diagnosed as adenocarcinoma and the number of tumors per mouse was significantly higher in SHN than in SLN. The tumors of both strains were hormone independent (Fig. 3) [21], and the growth potential of tumors was higher in SHN than in SLN when transplanted into female nude mice (Fig. 4).

While 1 out of $39(2.6 \%)$ mammary tumor bearing SHN mice had metastases to the lung, the ratio increased up to $23 \%(10 / 43)$ by elongation of survival time of animals by surgical removal of mammary tumors.

Both normal mammary growth (Fig. 6) and preneoplastic mammary hyperplastic alveolar nodule (HAN) formation (Fig. 7) were much more marked in SHN than in SLN.

SHN was superior to SLN in mammary sensitivity to prolactin and ovarian hormones, whereas no clear differences between strains were observed in plasma prolactin levels at different reproductive states (Fig. 8) [15, 27] or mammary gland prolactin receptor during lactation [15].

The pattern of estrous cycles of SHN females was characteristic in having long
\end{abstract}


continued diestrous phases (Fig. 9) [24]. Among several characteristics examined as the indices of reproductivity (Fig. 10), characteristics concerning lactational performance, litter growth and litter growth rate, became better with the advance of selection in SHN (Fig. 10-E, F, G, H).

The mammary tumor appearance was much higher and earlier in $($ SHN $\times$ SLN) $\mathrm{Fl}$ virgins than in ( $\mathrm{SLN} \times \mathrm{SHN}) \mathrm{Fl}$ virgins (Fig. 11), indicating higher mammary tumor virus (MTV) activity in SHN than in SLN. MTV antigen was identified by immunodiffusion test in the milk of both SHN (100\%) and SLN $(83 \%)[2]$. It was also found in prostates and seminal vesicles of males of both strains [36].

The responses of normal spleen cells and that of fat pad to PHA were significantly lower and higher, respectively, in SHN than in SLN.

一 総 説 -

\title{
同一基礎集団より乳癌高発および低発を \\ 指標として選抜確立された 2 つ近交系, \\ SHN および SLN 系マウスについて
}

\author{
長澤弘 \\ 国立がんセンター研究所 薬効試験部
}

はじめに

I . 基礎集団マウスの由来

II. 飼育条件

III. 選抜交配方式

IV. 乳癌の発生
1. 経産個体
2. 末経産個体

V. 乳癌の性質

1. 乳癌の組織像

2. 個体あたり乳癌発生数

3. 乳癌の増殖パターン

4. SHN 乳癌の, 制癌剤スクリーニングヘの応 用

5. 肺転移

VI. 発 育

はじめに

周知のよらに種々の乳癌発生率を有するいくつもの系 統のマウスが作られ, 広くその方面の研究に用いられて
VII. 乳腺の発育

1. 正常乳腺と HAN の発育

2. 乳腺発育とホルモン

3. 血中 prolactin レベル

4. 乳腺の prolactin に対する反応性一prolactin レセプター

VIII. 繁殖性

1. 胵開口日齢と体重

2. 発情周期の型

3. 繁殖成績

4. 繁殖性と乳癌発生率の関係

IX. 泌乳能力

$\mathrm{X}$ ，乳癌ウイルス

XI. 免疫応答性

おわりに

文献

いる。

乳癌の発生を指標として, 一つの集団のマウスを, 高 発および低発の 2 方向へ選抜することが可能であるか否 か, もし可能なら, 乳癌の発生に関与する種々の形質は, 


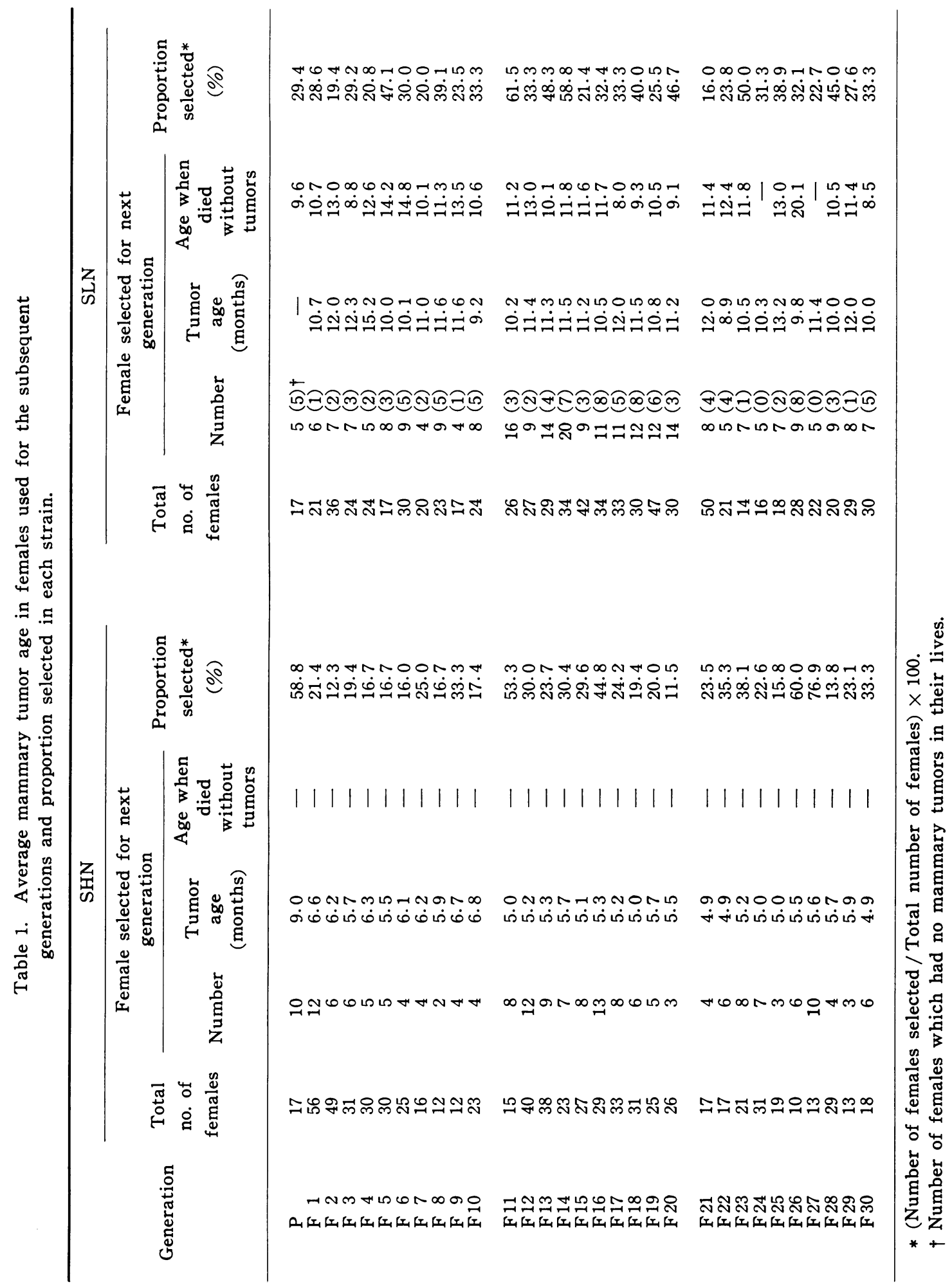


選抜の 結果どのように変化するかは, 乳癌発生の etiological な面から，きわめて興味あることと考えられる。

このよらな観点から，スイスアルビノマウスの一つの 基礎集団から乳癌高発拉よび低発の 2 方向一選抜を試み, SHN, SLN とい5 2 つの近交系を確立し $[27,30,31$, 34], 現在，それぞれ F 37，F31 に達している。

両系統マウスの F30 までに括ける発癌性や，それに 伴なら繁殖性の変化，および乳癌発生と関係ある種々の 形質の特徵, 系統間の差異などについての知見をまとめ た。

\section{I． 基葆集団マウスの由来}

選拔の基礎として用いられたスイスアルビノマウズ*1 は, City of Hope Medical Center (Durate, California, USA) 一一北海道大学—— 国立遺伝学研究所を 経て，1963 年に 国立がんセンター研究所に 移入され， 1964年 4 月より選抜が開始された。なお，同スイスアル ビノマウスは, 別に遺伝研より，1965年に，近交系 SW $\mathrm{M} / \mathrm{Ms}$ として登録されている。

\section{II. 飼育条件}

すべての世代において，育成中，未経産（virgin）， 繁殖，および retired の個体は，それぞれ同じ室の同じ ラックで飼育された。育成中，未経産，および retired マウスは, チップ入りのテフロンケージ $(18 \times 30 \times 12 \mathrm{~cm})$ に，6〜8匹ずつ収容した。繁殖個体は，同腹兄妹を一 対として同じケージに常に同居させた。動物室の室温は $24 \pm 1^{\circ} \mathrm{C}$ ，相対湿度 $65 \sim 75 \% ， 12$ 時間照明（午前 8 時〜 午後 8 時) で, 飼料は，日本クレア製 CA-1 を与光， 飲料水としては，動物用オーレオマイシン（武田）を $0.02 \%$ 添加した水道水を与えた。

ケージの交換と, 水のみの洗滌は週 2 回, ふたの交換 は月 1 回, 定期的に行なった。

*1 この集団のマウスは, 本来, 乳癌ウイルス (MTV) をもっていた。すなわち，出生直後から，MTVをも たない C57BL/6に哺乳 (foster nursing) された末 経産個体は，12力月齢までに 1 匹も乳癌の発生をみな かったのに対し，それ自身の母親に哺乳された未経産 個体の12力月龄に批既癌率は，およそ50\%であっ た[12]。

\section{III. 選抜交配方式}

各世代において，SHN では，できる限り早く発癌し た母親の子を，SLN では逆に終生発癌しなかったか， あるいはできる限り遅く発癌した母親の子を次代のため の交配に用いた。

その結果, 各世代に护基礎集団の発癌性は Table 1に示すよらになった。すなわち，SHN においては， 次代生産のために用いられた繁殖個体の平均発癌率は, 当然100\%で，発癌月齢は，F10 までは 6 力月以上のこ とが多かったが，F11 以降は 6 力月以下となった。これ ら選抜個体の平均発癌月齢と, 全群のそれとの差は 1 2 力月であった。SHN において母親の乳癌発生時に, まだ十分な子孫が確保されていない場合には, 随時, 乳 癌を外科的に除去して繁殖を続けさせた。

SLN においては，終生発癌しなかった個体のみを， 次代生産のための繁殖個体として用いるのがもっとも望 ましいが，あとにも述べるように，このような個体の繁 殖性は一般に低いこともあって，それだけでは必要な数 の子孫が残せないため，できる限り遅く発癌した個体も， 次代のための繁殖個体として用いた。実際には，選ばれ た個体の $50 \%$ 以上が発癌個体のことが多く，その発癌月 齢は 9 15力月齢であった。各世代に扑ける選抜個体の 割合 (proportion of selection) は, F20 ではSHN が SLNより小さかった。なお両系統とも, 各世代にお いて 2 産目の子を次代に用いることを原則とした。SHN では，これに関してとくに問題はなかったが，SLNで は，2 産目の子が交配適期になった時点では，ぞの母親 の子が選抜されるかまだ決定されないため, 数力月以上 にわたってかなり多数の繁殖マウスを維持しなければな らず，それがしばしばきわめて困難であったためと，2 産目のみでは必ずしも十分な子数が確保されないために, 実際には，とくに F15 以降，3〜5産目の子が次代の ために用いられることが多かった。

交配は前述のように兄妹交配とし, 初産日齢が発癌月 齢に影響する $[13,18]$ ところから，雌雄を常に同居させ， 乳癌発生, あるいは 6 産まで追いかけ妊娠 (concurrent pregnancy）させた。交配開始後, あるいは前回分婏後 2 力月経過しても妊娠しなかった個体は繁殖を中止した。 産子は 1 腹子が 8 匹以上の場合は 8 匹まで減らしたが, 8 匹以下のときは，とくに子数の調整は行なわなかった。

\section{IV。乳癌の発生}



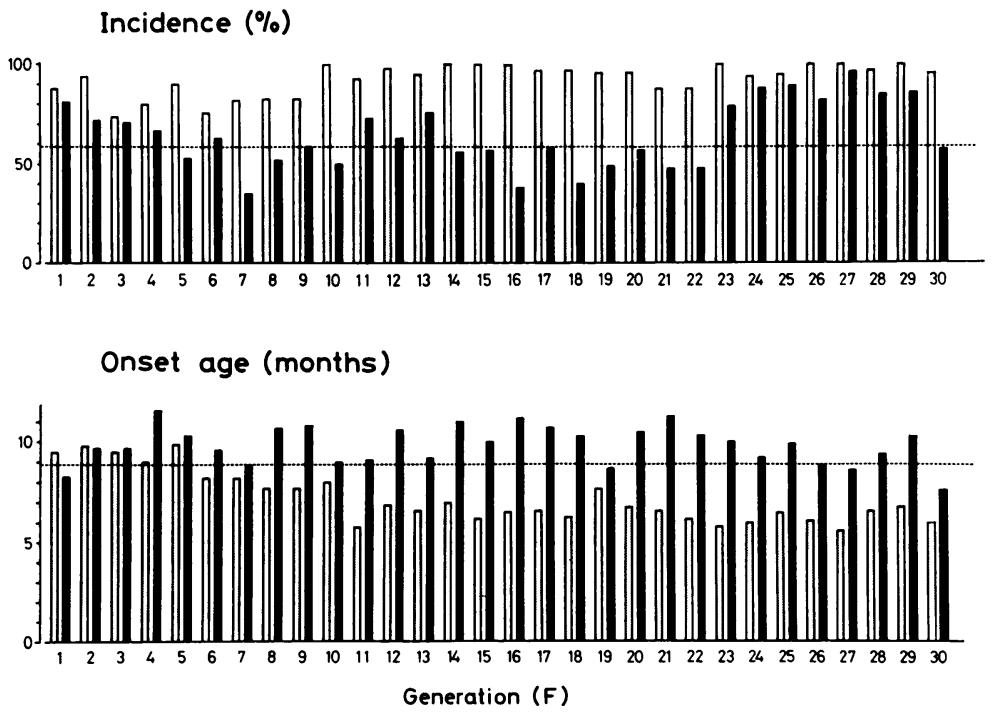

Fig. 1. Mammary tumorigenesis in breeders of each strain. SHN, $\square$ SLN. …. Mean value at $\mathrm{P}$ generation.

See Table 1 on the number of mice examined in each generation.
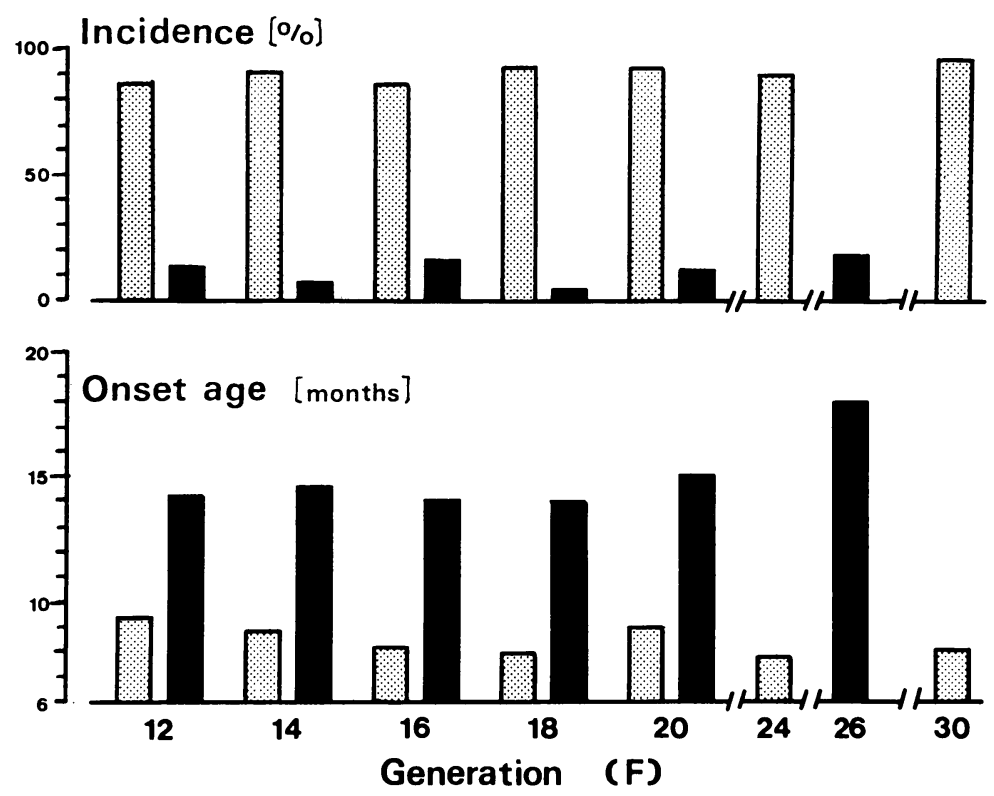

Fig. 2. Mammary tumorigenesis in virgins in each strain. $\$$ SHN, $\quad$ SLN. Number of mice is $21-60$ in each generation. 
すべての経産個体は, 毎週 1 回触診により,生涯発癌 をチェックした。乳癌の大きさは 2 長径の幾何平均值で あらわした。F12-20 に扎いては一世代拉きに，それ以 後は数世代括きに末経産個体の乳癌発生もチェックした。

1. 経産個体

繁殖個体に找ける乳癌発生率および発癌月齢の变化を Fig. 1 に示す。SHN においては，乳癌発生率は，世 代を経るに従って上昇し，F10以降は，ほとんどすべて の個体が発癌した。また発癌月齢も世代とともに早まり， これも F11 以降，ほぼ一定して $6 〜 7$ 力去なり， $\mathrm{P}$ 世代との間に 3 力月近くの差の恋められる世代が多かっ た。

一方, SLN においては, 発癌率, 発癌月齢とも世代 間の变異は大きく, 選拔の効果は必ずしも顕著ではなか ったが，発癌月齢の若干遅れる傾向が認められた。F23 以降, 系統維持の必要上, 基礎集団のサイズを大きくす る目的から，比較的早い時期に発癌した個体も，次代の ための基礎集団に加えられたため, 発癌率は急激に上昇 している。

なお，未発密個体の寿命は，両系統とも，6〜15力月 であったが，そのばらつきは著しく大きかった。

\section{2. 未経産個体}

両系統における未経産個体の乳癌発生率打よび発癌月 齢を Fig. 2 に示す。SHN では F12 以降，90\%以上 の発癌率と，8〜9力月の発癌月齢を示した。

SLN では, 経産の場合と異なり, 未経産個体では, 選抜の効果は顕著で, 乳癌発生率は10～20\%，発癌月齢 は14〜18カ月であった。

末発癌個体の寿命は, SHN, SLN それぞれ8～14力 月, 13〜19力月であったが, 経産の場合と同様, 各世代 とも，個体間のばらつきは著しく大きかった。

\section{V. 秏癌の性質}

\section{1. 乳虎の組織像}

両系統とも，できる限り多くの乳虎を組織学的にチェ ックしたところ，すべて adenocarcinoma と琹められ た。また SHN マウスの乳癌について, さらに詳細に分 類すると， adenocarcinoma type A, B, AB が， そ れぞれ $15.1 \% ， 51.6 \% ， 33.3 \%$ あった [26]。

\section{2. 個体あたり乳癌発生数}

両系統とも, 死亡時をでの繁殖個体あたり最も多い乳 癌発生数は 4 ケであった (SHN, 18\%；SLN, 1.5\%)。 一方，1 ケしか発癌しなかった個体は，SLNでは扰よ

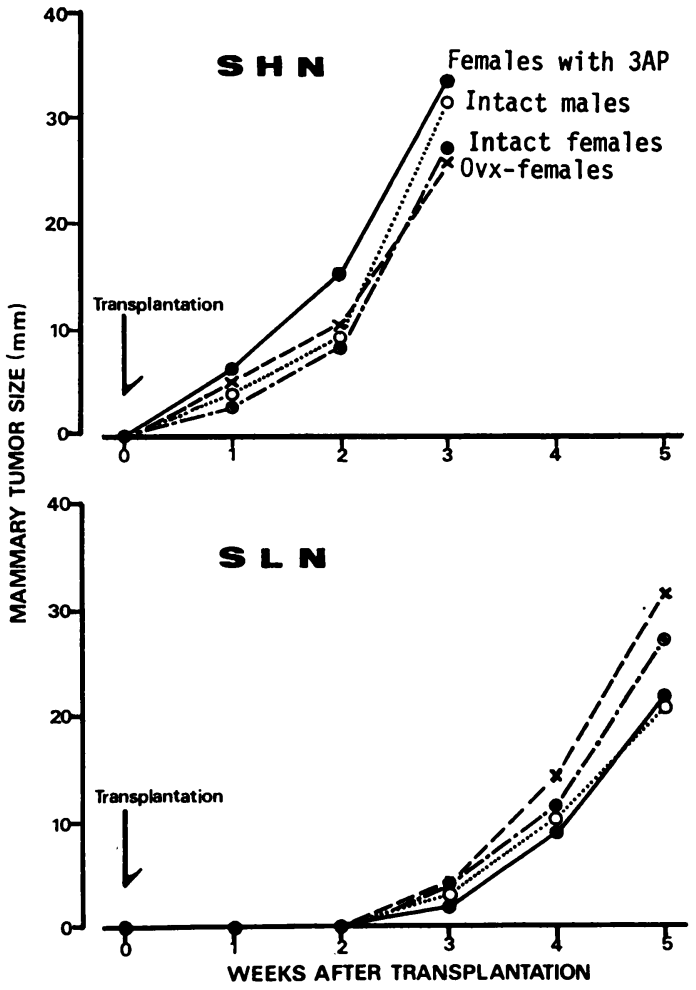

Fig. 3. Growth curves of mammary tumors from each strain transplanted into hosts with different hormonal conditions. 3AP : isologous grafts of 3 pituitaries, ovx : ovariectomized [21].

そ60\%，SHN では28\%であった [27]。

未経産個体では, SHN の40\%以上が $3 \sim 4$ ケ発癌し たのに対し，SLN ではすべて1ケ（75\%）か 2 ケ（25 \%)であった [27]。

3. 乳癌の增殖パターン

最初に発生した乳癌の增殖の変異は両系統とも著しく 大きく，また増殖のカーブに明らかな系統差は認められ ていない [21]。また二番目以降に発生した乳癌の增殖 との関係にも一定の傾向は認められなかった。

一方, 約 $10^{6}$ ケのこれらの乳癌細胞を, 種々のホルモ ン条件にある，それぞれの系統の host，すなわち正常 雌, 正常雄, 卵巣除去雌, 下垂体 3 ケを腎皮膜下に移植 された倠，に移植したところ，両系統とも host の違い による乳癌の増殖のパターンに差はみられず，これらの 乳虎のホルモン依存性は明らかでなかった。しかし移植 された乳癌細胞が palpableになるまでの期間は，SHN では 1 週間であったのに対し，SLN では 3 週間を要し 


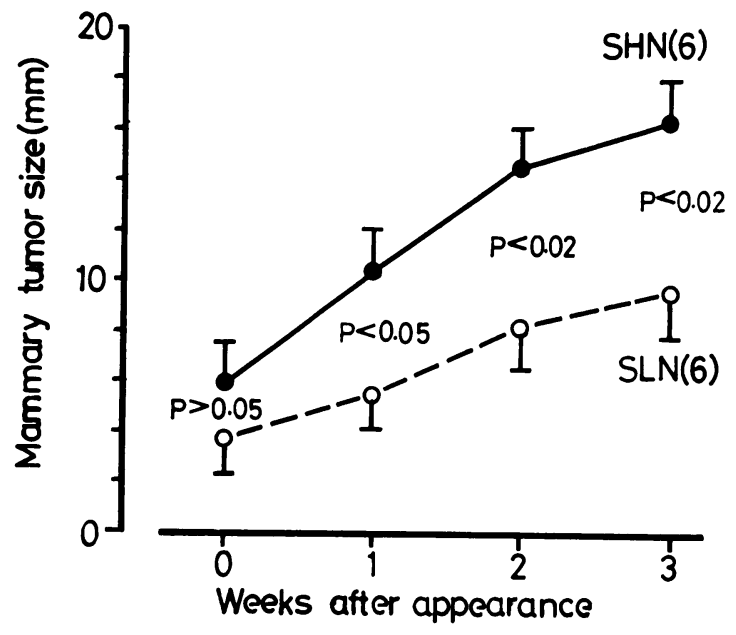

\begin{tabular}{|c|c|c|c|}
\hline $\begin{array}{c}\text { SOURCE OF } \\
\text { MAMMARY } \\
\text { TUMORS }\end{array}$ & $\begin{array}{c}\text { NO, OF } \\
\text { TUMORS } \\
\text { TRANSPLANTED }\end{array}$ & $\begin{array}{c}\text { LATENCY } \\
\text { PER IOP } \\
\text { (WEEKS })\end{array}$ & $\begin{array}{c}\text { MAMMARY } \\
\text { TUMOR } \\
\text { WE IGHT } \\
(G)\end{array}$ \\
\hline S H N & 6 & $3.0 \pm 0.0$ & $1.7 \pm 0.6$ \\
S L N & 6 & $4.2 \pm 0.5$ & $0.6 \pm 0.2$ \\
\hline
\end{tabular}

Fig. 4. Growth curve of mammary tumors of each strain transplanted into intact female nude mice (means \pm S.E.M.) [16].

た (Fig. 3) [21]。

さらに各系統の乳癌細胞を, 正常皆ヌードマウスに移 植したところ，すべて take したが，その時期は，SHN の方が SLN より早く（3.0および4.2週），また增殖も SHN の方が著しかった (Fig. 4) [16]。これら一連の 移植実験の結果, SHN 乳癌の増殖の potential はSLN のそれより高いことがらかがわれた。

4. SHN 乳癌の, 制癌剤スクリーニングへの応用 いらまでもなく，すべてのヒトの癌は, “自然発生” であって，移植系になった癌とは，多くの点で全く異な った性質のものである。それにもかかわらず，制癌物質 のスクリーニングには，もっぱらこの移植癌が用いられ てきている。最近，これに対し，SHN マウスに発生し た乳癌を外科的に摘出し，ただちにその一部（約 $1 \mathrm{~mm}^{3}$ の小片，あるいは1 $10^{5}$ ケの細胞）を摘出部位に戾し, 種 々の被検物質を局所的，あるいは全身的に投与して，そ の制癌性をスクリーニングする方法が確立された $[35$, 36]。SHN マウスは, 経産, 未経産とも, 発癌率は高 く, 発癌月齢は早く, その変異も此較的小さいため, こ の方法のためにもきわめて有用な茲統と思われる。

5. 肺転移
ヒトの乳癌と, マウスなどにおける実験的乳癌とのも っとも大きな違いの一つは, 前者では, 肺, 骨, 肝など への転移が多く，これが治療上もっとも深刻な問題とな っているのに対し, 後者ではその転移のきわめて稀なこ とである。マウスの自然発生乳癌は, 今後とも, もっと も重要視されるべき乳癌のモデルであるから，その乳癌 の転移率を高めることができれば，モデルとしての効用 は著しく増すと考えられる。この観点から, 転移率を高 める一つの試みとして, SHN マウスに発生した乳癌を 外科的に摘出して延命を図った際の, 肺への転移をチェ ックした。乳癌発生マウスを無処置のままでおき，死亡 した時点に拈ける肺への転移は39匹中 1 匹であったが， 乳癌を摘出して延命を図ったマウスに拈ける肺転移は43 匹中10匹で，著しい転移の増加をみた。個体あたり発生 乳癌数は打よそ3ケで, 肺転移をみた個体之, 転移のな い個体で差はみられなかった [39]。

一方, C3H/HeNSa 系雌マウスでは, 自然発生乳癌 の肺転移率は $39.4 \%(26 / 66)$ といら報告があり [32], 此の点に関しての系統差の存在が示唆された。

\section{VI. 発充}

両系統マウスの発育曲線は Fig. 5 に示す通りで, 雌 雄とも100日齢以降で, SLN の方が若干重くなる傾向が 認められた $[27]$ 。

\section{VII。勫腺の発育}

\section{1. 正常乳腺および $\mathrm{HAN}^{* 2}$ の発育}

ホールマウント標本でみる限り, 未経産個体の乳管の 分枝, 発育には系統間にとくに差はみられない。しかし 乳腺胞系の発育は，SHN では月龄とともにさかんとな

*2 乳腺における HAN (hyperplastic alveolar nodules) (Fig. 6-3) は, 正常乳腺の乳腺胞系が局所的 に異常增殖したもので, いわゆる乳癌の前癌症状と考 えられており，ある月齢以上のすべての乳癌高発系、 ウスの乳腺に認められる。HAN は, 組織学的にも細 胞学的にも, 正常な乳腺胞系と全く変らず, 高いホル モン依存性を示す。しかしその増殖能, ないしホルモ ンに対する反応性は, HAN の方が正常乳腺胞より著 しく高い。しかし個々の HAN の性質はさまざまで， もちろん HAN のすべてが乳癌になるわけではない $[5,6]$ 。 


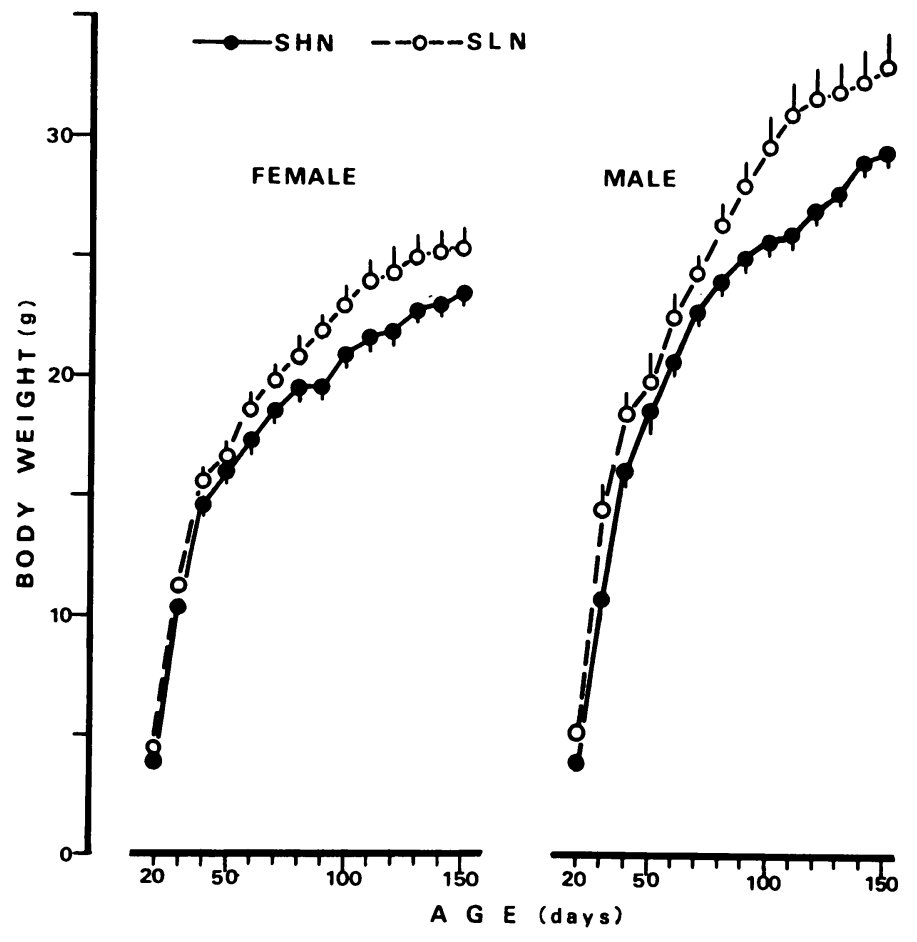

Fig. 5. Growth curve of females and males in each strain (means \pm S. E. M.) [27].

るのに対し, SLN では妊娠しない限り, 乳腺の発育は ほぼ乳管系のみに止まる (Fig. 6)。

また HAN 形成も，SHNでは，月齢とともに増加す るが，SLN では， 6〜 7 カ月齢でようやく $10 \%$ 程度の 個体に HAN 形成がみられた（Fig. 7)。SHN におけ る個体あたりの HAN 数は， 月齢のす寸むにつれて增 加する傾向を示した (Fig. 7)。

\section{2. 乳腺発育とホルモン}

F1 および F7 に执いて, 両系統の卵巣除去雌マウス ( 3 力月齢) 飞, estrogen depot $(25 \mu \mathrm{g})+$ progesterone depot ( $5 \mathrm{mg})$ を, 週 1 回, 4 週間皮下注射し, 乳腺胞の発育を比較した。F1では両系統とも100\%の乳 腺胞の形成を示したが，F7に㧊ける形成度は，SHNの 100\%に対し，SLN では33\%であった[19]。

また，28３2日齡の両系統の䧳マウスに, estradiol一 $17 \beta(1 \mu \mathrm{g})+$ progesterone $(1 \mathrm{mg})$ を 3 日間前処 置（皮下注射）し（この時点では，両系統の乳腺とも乳 管のみよりなり，発育に差は全くみられない)，翌日よ $\eta$ Banerjee et al [1] の方法により, 片側胸部第二全 乳腺をWaymouth の培養液中で種々の期間培養し, 乳腺の発育を比較した。培養液に添加されたホルモンは,
1) Insulin $(5 \mu \mathrm{g} / \mathrm{ml})$, aldosterone $(1 \mu \mathrm{g} / \mathrm{ml})$, estradiol-17 $\beta(1 \mathrm{ng} / \mathrm{ml})$, progesterone $(1 \mu \mathrm{g} / \mathrm{ml})$, ovine-prolactin $(5 \mu \mathrm{g} / \mathrm{ml})$, bovine-GH $(5 \mu \mathrm{g} / \mathrm{ml})$

2) Prolactinの代りに Human placental lactogen を,

3) Estrogen あるいは progesterone の濃度を10倍 に,

4）Prolactin, GH をラット由来のものに,などであ る。どのホルモンの条件においても, 乳腺胞系の発育に, 顕著な効果の違いはみられなかったが，いずれの場合に も, SHN における発育は, SLNに护けるよりはるかに 著しかった。この系統間に打ける違いは, 主としてどの ホルモンに基くものであるか，すなわち，上記各ホルモ ンのらち, どれがもっとも重要なホルモンであるかにつ いては，引き続き検討中である $[40]$ 。

3. 血中 prolactin レベル

Prolactin は, マウスにおいても正常乳腺の発育中乳 癌の発生にとって，もっとも重要なホルモンである [5, $6,14,38]$ 。前述のよ5に, 乳腺の発育に著しい差のある SHN, SLN においては，下垂体から分泌される prolactin のレベルに差のあることが考えられる。この観点 

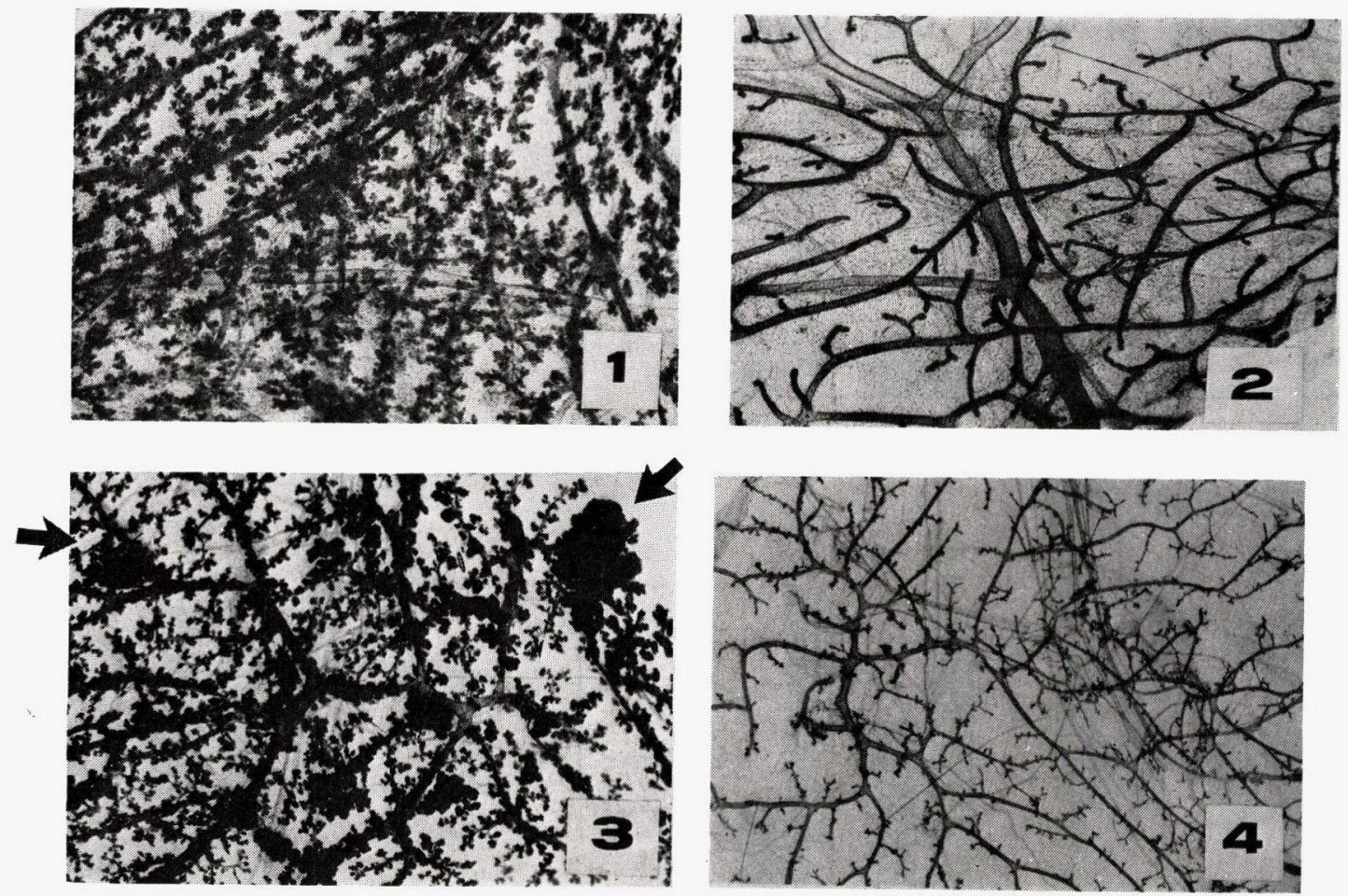

Fig. 6. Representative wholemount preparations of mammary glands

in each strain (hematoxylin, $\times 5$ ) [27].

1. SHN virgins at 3 months.

2. SLN virgins at 3 months.

3. SHN virgins at 7 months.

4. SLN virgins at 7 months.

から, 未経産, 妊娠, 泌乳の各期に捺ける血中 prolactin レベルを radioimmunoassayにより測定した。結果は Fig. 8 に示す通りで, およそ2力月柃の発情期に打いて は, SHN はSLN より高く, 妊娠 19 日目にはその逆 [27], 泌乳 4, 9 日目では, 系統間に差なく $[15]$, 必ず 乙も一定の傾向は認められていない。このことは, 乳癌 の発生を指標としての選抜が, 下垂体からの prolactin 分泌能にはあまり影響を扰よぼさなかったことを示唆す るものである。事実, 乳癌の発生に対しては, 体内の prolactin レベルより, 次にのべる乳腺の反応性の方が より重要であることが, 実験動物においても $[14]$, ヒト においても [9]指摘されている。

4. 乳腺の prolactin に対する反応性—-prolactin レセプター

Prolactin に対する乳腺の反応性をチェックするため, 乳腺の発育がまだ乳管のみで, 系統間に差のみられない 50 日齢の正常雌マウスの腎皮膜下に, 両系統間 F1 の下
垂体を 3 ケずつ移植し（移植された下垂体からは主とし て prolactin のみが持続的に分泌される)，20日後に乳 腺の発育をホールマウントで調ベたところ，SHN では SLN よりその発育は，はるかに著しかった $[27]$ この ことは, 乳腺の prolactin に対する反応性に执いて, SHNはSLN より高いことを示すが，これが prolactin の乳腺に対する直接作用のみとはいえず，卵巣からの estrogen や progesterone 分泌に変化をきたした結果 をも考慮しなければならないことはいらまでもない。

ここ数年, ホルモンの反応性の指標としてのレセプタ 一の測定がきわめてさかんであり，そのような目的から， 乳腺や乳癌の細胞膜における prolactin レセプターの問 題についても多くの報告がみられる $[8,20]$ 。しかし， prolactin レセプターは, 必ずしも細胞の反応性のよい 指標とはならないことが指摘されている。前述のよらに, 乳腺の発育のみならず, 泌乳能力や, 乳癌の発生率など に拉いても著しい差のある SHN, SLN で, 泌乳4 日 


\section{Percent of mice with HAN}

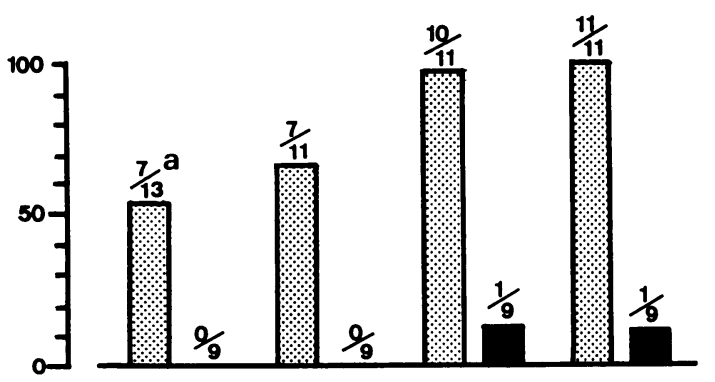

\section{No of HAN}

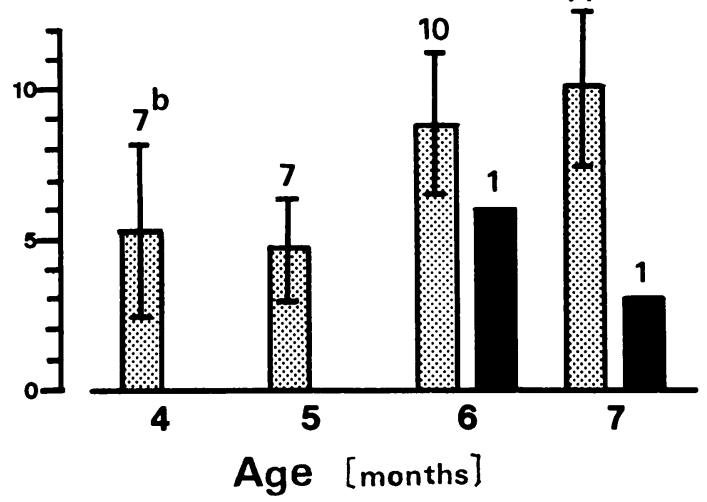

Fig. 7. Formation of mammary hyperplastic alveolar nodules (HAN) in the right third thoracic gland of each strain (means \pm S.E.M.) SLN.

a Number of mice with HAN/Number of mice examined.

b Number of estimates.

目および 9 日目の乳腺細胞の prolactinレセプターを測 定したところ, その結合能, 結合部位数, affinity の いずれにも差はみられなかった［15]。

\section{VIII．殖 性}

\section{1. 腔開口日齢と体重}

Table 2 に示すよ5に, SHN はSLN より腔開口日 齢は早く, 腔開口時体重は小さかった。また両系統とも 開口日齢と体重の間に有意の相関関係が認められた。

2. 発情周期の型

腔開口直後における発情周期の型は, 不規則ながら 4 〜 6 日ごとに発情を繰り返し，系統間に明らかな違いは

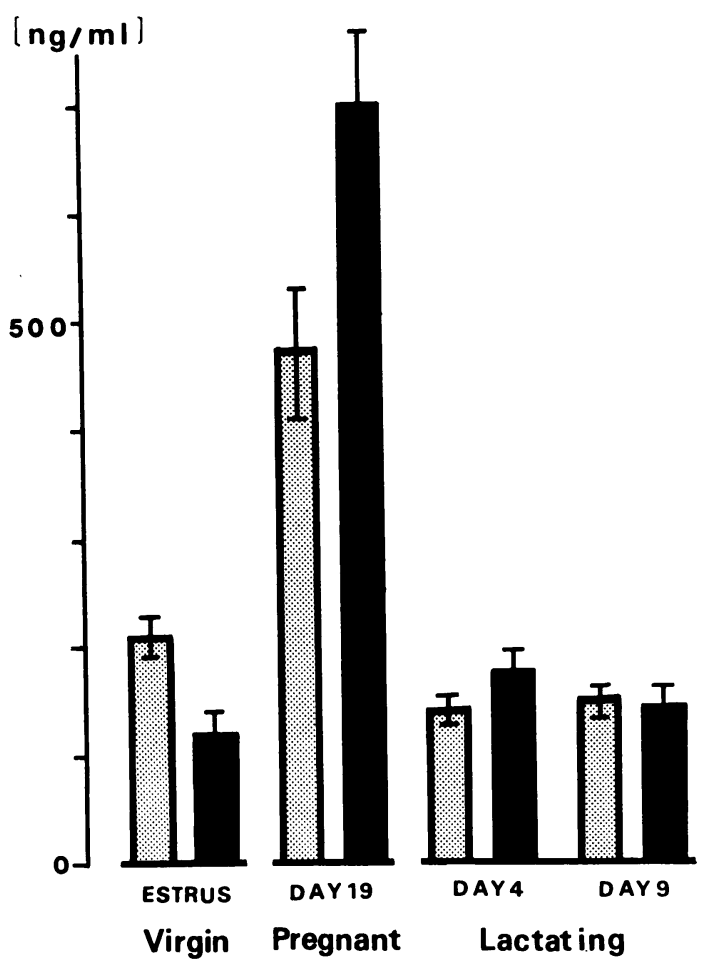

Fig. 8. Plasma prolactin levels during the different reproductive states in each strain (means \pm S.E. M.). SLN. [15,27].

みられなかった。しかし，3〜4 カ月龄においては， Fig. 9 に示すように, SLN ではかなり規則的な周期を 繰り返すのに対し，SHN では10日以上の長い発情間期 が頻繁にあらわれるようになった。平均発情周期および

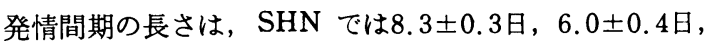
SLN では $4.6 \pm 0.1$ 日，2.5 0.1 日であった [24]。同様 な発情周期の型における明らかな系統差が, 別の乳癌高 発系の $\mathrm{C} 3 \mathrm{H} / \mathrm{He}$ と, 低発系の $\mathrm{C} 57 \mathrm{BL} / 6$ の間にもみら れている [17]。

3. 繁殖成績

Fig. 10 と示すような, 繁殖性の指標としての12の形 質について, 各世代, 各個体, 各産次別に測定した。

常に雌雄を同居させて追いかけ妊娠を図る交配システ ムに护分婏間隔 $(A)$, 分婏時母体重 $(B)$ には, 両系 統とも，選抜に伴なら著しい変化はみられなかった。

SHN の産子数(C)は, F10 まで若干低下したが, そ れ以降はほぼ P世代の值を維持した。SLN では，世代 の進行とともに，産子数は明らかに低下した。 
Table 2. Age and body weight at vaginal opening in each strain (means \pm S. E. M.)

\begin{tabular}{lcccc}
\hline Strain & $\begin{array}{c}\text { No. of } \\
\text { mice }\end{array}$ & $\begin{array}{c}\text { Age(a) } \\
\text { (days) }\end{array}$ & $\begin{array}{c}\text { Body weight(b) } \\
(\mathrm{g})\end{array}$ & $\mathrm{r}_{\mathrm{ab}}$ \\
\hline S H N & 20 & $26.7 \pm 0.6^{* * *}$ & $15.1 \pm 0.3^{* * *}+0.789^{* * *}$ \\
S L N & 20 & $33.0 \pm 0.5^{* *}$ & $19.2 \pm 0.2^{*}+0.488^{*}$ \\
\hline$* * * \mathrm{P}<0.01, \quad * \mathrm{P}<0.05$. & &
\end{tabular}
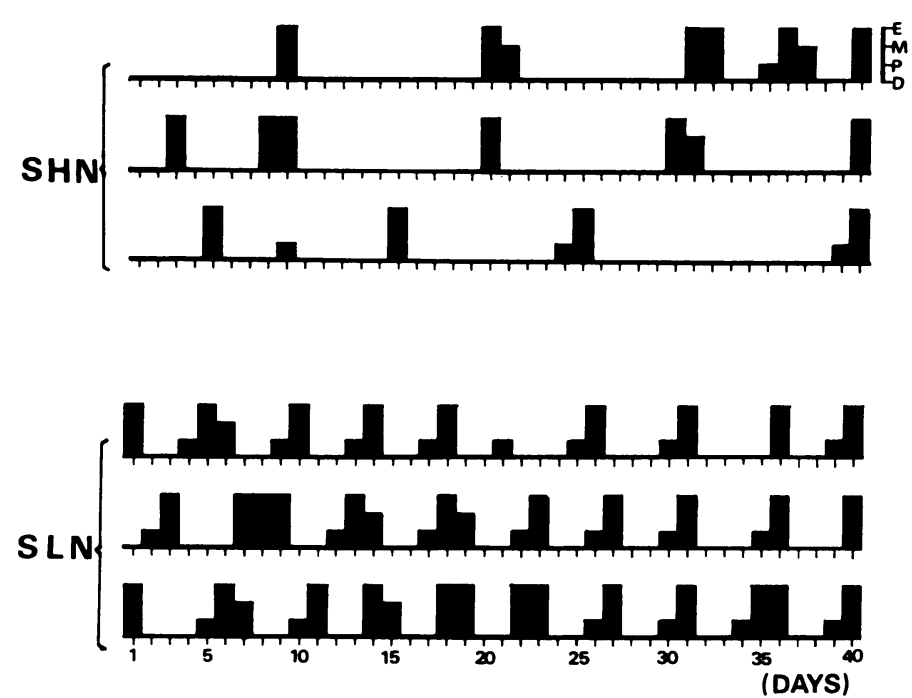

Fig. 9 Representative patterns of estrous cycles at 3-4 months of age in each strain. E, estrus ; $M$, metestrus ;

$P$, proestrus ; $\mathrm{D}$, diestrus.

0 日齢子体重 $(\mathrm{D})$ には, 系統間，世代間に著しい違い はみられない。SHN の12日齢子体重(E)は，選抜がす すむにつれて著しく増加した。SLN では，F20 までP 世代のレベルを維持し，あまり変化しなかったが，その 後上昇した。20日齢子体重(F)は，F20 までは SHNで はほぼP世代のレベル，SLN では若干低いレベルを維 持したが，両系統ともF21 以後上昇した。

12日齢子增体率(G)に批いて, SHN では選抜のすす むにつれてほぼ直線的に増加した。SLN では F21-25 を除いて，とくに顕著な変化はみられなかった。20日齢 子増体率 $(\mathrm{H})$ において, SHN では，12日齢の場合とほ ぼ同様の傾向が認められたが，SLN においては，F15 まで $\mathrm{P}$ 世代より若干低かったが, F21 以降, 逆に $\mathrm{P}$ 世 代より高い值を示した。

12日および20日齢までの育成率 $(\mathrm{I}, \mathrm{J})$ において，SHN

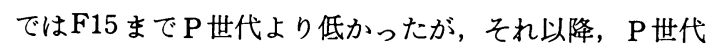
のレベルを維持した。これは, 外科的手術による乳癌の 除去をできるだけ早期, かつ頻繁に行ならよう心がけた ため, 乳癌発生による哺育能力の低下を防ぎ得た結果と 思われる。これに対し，SLN ではF20まで育成率は常 に低く，F25以降上昇した。両系統に拈ける高い死産率 (K)は, 主に 1 産目のそれに起因する。死産子率(L)は SHN で低かった。

以上の結果, 乳癌の発生を指標とした選抜は, 繁殖性 のらち, 子の体重や増体率に，とくに著しい影響をもた らしたことが知れた。

4. 繁殖性と乳癌発生率との関係

前述のように，SLN においては次世代のために用い る基礎マウスの選抜を厳重にすると, えらばれた個体の 繁殖性は一般に低いため, 次世代に必要な数の子を確保 


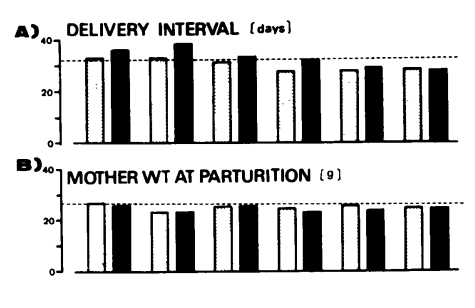

c) LitTER SIZE
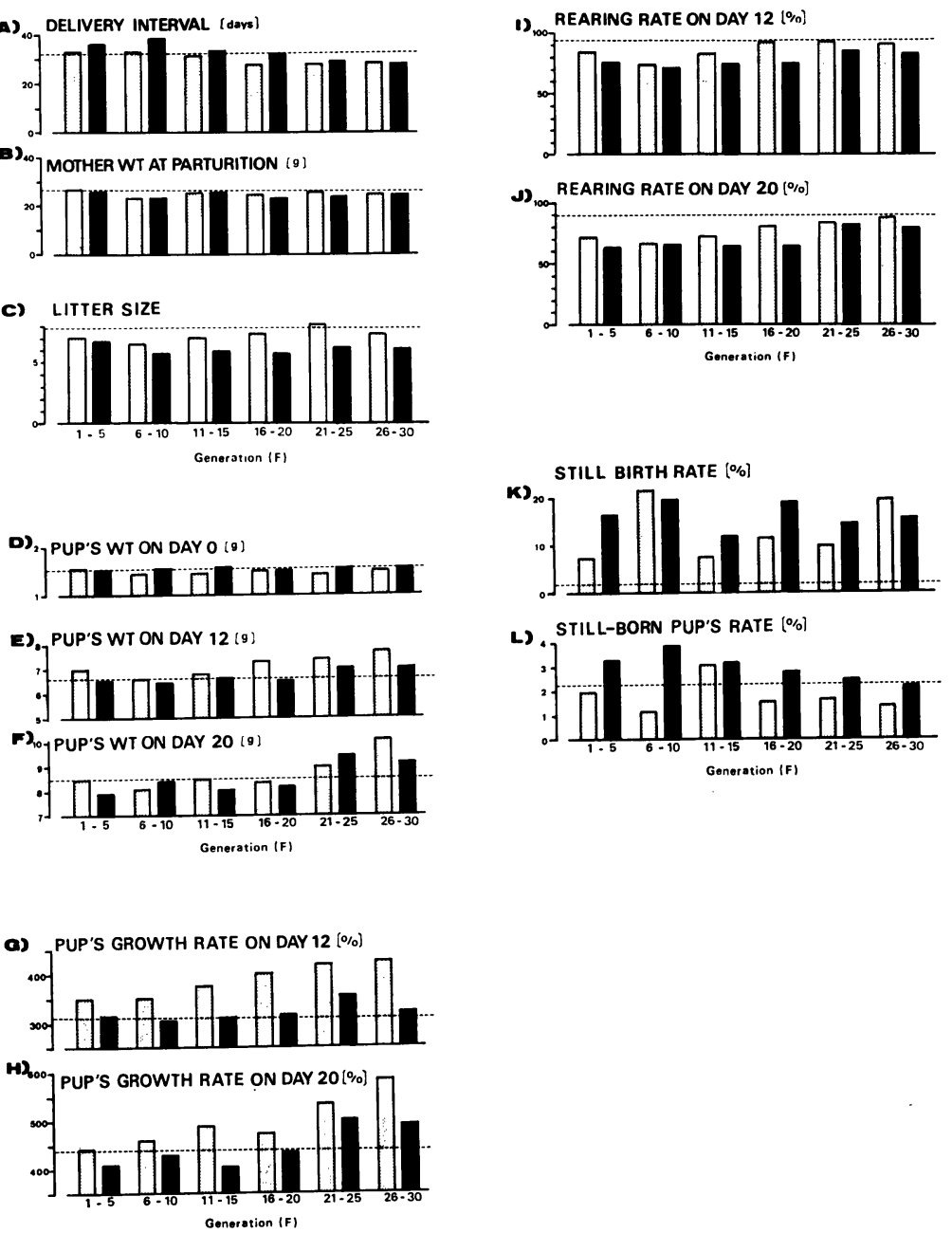

Fig. 10. Characteristics as the indices of reproductivity in each strain. $\mathrm{m}$ SHN, SLN. ...... Mean at $\mathrm{P}$ generation.
$G, H: \frac{\text { Av. wt. of pups on day } 12 \text { or } 20-\text { Av. wt. of pups on day } 0}{\text { Av.wt. of pups on day } 0} \times 100$
$I, J: \frac{\text { Number of pups on day } 12 \text { or } 20}{\text { Number of pups on day } 0} \times 100$

することがしばしば困難となった。そのため選抜の基準 をゆるめると，次世代の確保が可能になると同時に，そ の世代の乳癌発生率は急速に増加する。このようなジレ ンマを持ちつつ同系統 (SLN) は維持されているが, は たして, 繁殖性のらち, どの形質が乳癌発生と密接な関 係をもっているかを知るため，F2-F28 における各世代 の乳癌発生率と上記各形質との間の単純相関, および産 次数あるいは 0 日齢子体重を一定にした際の偏相関を算
出したところ，12日，20日跲の子体重や増体率と乳癌発 生率の間に有意の相関が得られた [11]。このことは， SHN に打いて，選抜の結果，繁殖性のうち，とくに12 日，20日齢子体重や，增体率の上昇が顕著であったこと， および SLN において F 23 以降, 乳癌発生率の上昇 (Fig. 1) に伴なって，12日，20日齢子体重 (Fig. 10E，F)，および增体率 (Fig. 10-G，H) が上昇している ことからもらなづける。すなわち,これらの結果は, 繁 


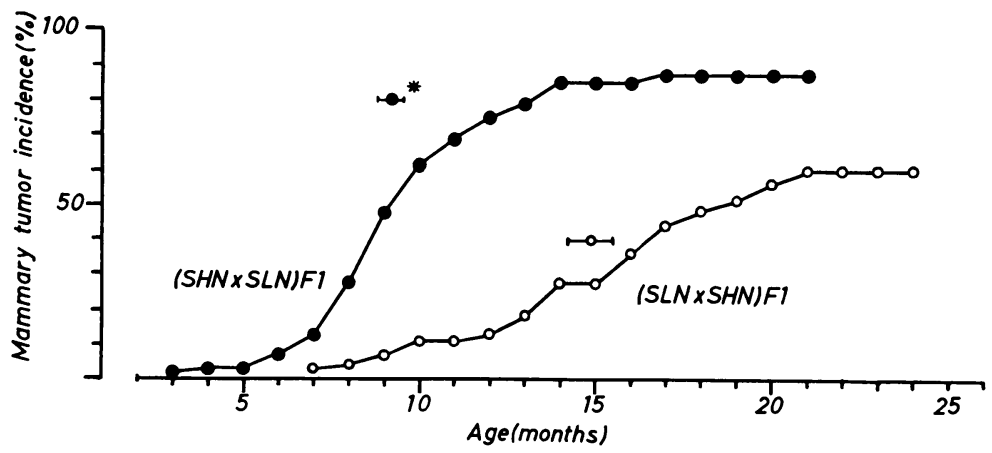

Fig. 11. Mammary tumorigenesis in Fl-hybrid females between SHN and SLN. * Average onset age of tumors with S.E.M.

殖性の中では母親の泌乳性が乳癌発生の一つの大きな要 因であることを示すものである。その理由としては，10 泌乳能力と乳腺実質量とは平行関係にあること $[3,4,25]$, すなわち泌乳能力の高い個体は乳腺実質も多く, それだ け乳腺細胞の癌化の危険度は大きいと考えられる。(2)マ ウスの乳癌発生には, 乳汁, その他を通して子に伝えら れる乳癌ウィルス (MTV) が一つの主要な要因となる が, 泌乳能力の高い一ーミルク生産量の高い一一個体ほ ぞ，子に伝えられる乳癌ウイルス (MTV) の量も多い であろらこと,などが考えられよう。

\section{IX. 泌乳 能力}

前述のように, 12日, あるいは20日齢の子体重や子増 体率が，SHN では，選抜のす寸むにつれて上昇した。 このことは乳癌の発生を指標としての選抜が泌乳能力の 向上を伴なったことを示唆する。この点をさらに確かめ るため, 両系統の間の F1 を作り, それぞれの母親に哺 乳させたところ，12日踚子体重, 増体率とも, SHN に 哺育された $(\mathrm{SHN} \times \mathrm{SLN})$ F1 は，SLN に哺育された $(\mathrm{SLN} \times \mathrm{SHN}) \mathrm{F} 1$ より有意に高い值を示し, SHN の 泌乳能力は SLN のそれよりすぐれていることが知れた $[27]$ 。

\section{X. 釈癌ウィルス}

乳癌の発生を指標としての選抜が，マウスの乳癌発生 にとって主要な要因である乳癌ウイルス (MTV) の活 性にどのよらな影響をおよぼしたかを検討する一環とし て，両系統マウスの F1 をそれぞれの系統の母親に哺育 させ，その乳癌発生率をチェックした。その結果，Fig. 11 に示すよらに, SHN に哺育された $(\mathrm{SHN} \times \mathrm{SLN})$ F1 では, SLN に哺育された $(\mathrm{SLN} \times \mathrm{SHN}) \mathrm{F} 1$ より
はるかに高い乳癌発生を示した。F1 の遺伝的素性は同 じと考えられるから，この乳癌発生率や発癌月齡に打け る差は，母親によって伝えられた MTV の活性の差に よるものと考えられる。この結果は, 乳癌の発生を指標 としての選抜が MTV 活性にも違いをもたらしたこと を示す。ただし，これが，伝えられた MTV の量によ るものか, 個々の MTV の質に差異を生じたのか, あ るいはその両者によるものであるかは明らかでない。こ れらの点は, 目下検討中である。

最近, MTV の抽出技術の進歩とともに, MTVを 免疫学的に測定する方法が急速に発展してきた。SHN, SLN 両系統の $1 \sim 3$ 産に打ける乳汁中の MTV 抗原 を immunodiffusion testによってチェックしたとこ ろ, SHN では 100\% (18/18), SLNでは 83\% (10/12) に，抗原の存在が認められた $[2]$ 。

また，同じテストによって，(BALB/c × SHN) F1, $(\mathrm{BALB} / \mathrm{c} \times \mathrm{SLN}) \mathrm{F} 1$ ，およびそれらの戻し交配一代 $\left(\mathrm{BC}_{1}\right)$ の乳汁中, さらには, SHN, SLN 両系統の雄 の前立腺および精のらにも MTV の存在が認められた [37]。これらの結果は, SHN, SLN の雄も MTVを もち, それが次代に伝えられる可能性を示唆するもので ある。

さらに, MTVは, 発癌因子としてのみではなく, prolactin 分泌 [33] や, prolactin に対する乳腺の反応 性 [23]にも関与することが知られて拈り, これらの面 からの MTV 研究の重要性が強調されている [10]。

\section{XI. 免疫応答性}

他の癌におけると同様, 乳癌の発生に対しても, 個体 の免疫能が一つの要因として注目されつつある。事実, SHN マウスの免疫能を高めることによって乳癌の発生 
を抑制し $[22]$, 逆に, SLN マウスの免疫能を低めるこ

とによって乳癌の発生を促進させ得た $[7]$ 。

SHN, SLN 両系統の免疫応答性をチェックするため, PHA, ConA, LPS に対する脾リンパ球の忘答, SRBC に対する脾の抗体産生細胞と足踫反応, BCG 感作後の PPD に対する足踓反応などが系統間で比較された。 SHN 倠において，PHA に対する脾リンパ球の反応が， SHN 雄および SLN 倠雄より低く，またPHA に対 する足瞊反応は高かった。そして SHN 雌におけるこの PHA 反応は, 乳癌発生の頃にとくに顕著で, 両者の間 の平行関係がらかがわれた。 SRBC に対する抗体産生 と遅延型の反応, および BCG に対する遅延型の反応で は, 両系統の間に差がなく，いずれも高い応答性を示し た [29]。

また, Carbon Clearance テストにおいて, SHN は SLN より clearance の低い傾向が認められており [28], SLN の方が SHN よりマクロフアージ活性の高いこと が示唆された。

\section{おわりに}

これまでの一連の研究により, 乳癌の発生を指標とし てのマウスの選抜は, 正常乳腺の発育, ホルモンに対す る乳腺の反応性, 繁殖性, 泌乳性, MTV 活性, 免疫応 答性など, 乳癌の発生に直接, 間接に関与する形質に著 しい変化をもたらしたのみならず, 発生した乳癌の増殖 能にも影響をおよぼすことが知れた。同一の祖先をもち， かつ多くの点で，その特性を異にする SHN, SLN を 適宜比較しつつ, 種々の乳癌研究に用いることはきわめ て有効と思われる。

\section{榑谷和男薬効試験部長の絶えざ御助力に感謝する。}

著者の研究室における両系統の確立, 維持, およびこれに関す る研究は, 長年にわたる文部省科学研究補助金 (がん特別研究 I : 川俣班) の助成の下, 矢内玲子博士, 谷口 寿, 中島裕子両氏 の協力によって行なわれているものである。

\section{文献}

[1] Banerjee, M. R., Wood, B. G., Lin, F. K. and Crump, L.R. (1976). Organ culture of whole mammary gland of the mouse. TCA Manual 2, 457-462.

[2] Imai, S., Morimoto, J. and Tsubura, T. (1979). Mode of MTV-antigen expression in the milk from five inbred mice strains established in Japan. Gann, (投稿中).

[3] Moon, R. C. (1962). Mammary gland cell content during various phases of lactation. Amer. J. Physiol.,
203, 939-941.

[4] Nagai, J. and Sarkar, N. K. (1978). Relatioship between milk yield and mammary gland development in mice. J. Dairy Sci., 61, 733-739.

［5］長澤 弘 (1971). 実験的乳癌に対する prolactin の役割 (その 1). ホルモンと臨床, 19, 625-629.

[6] 長澤 弘 (1975). プロラクチンと乳癌 (綜説). 代謝, 12 , 1028-1036.

[7] Nagasawa, H. (1977). Effect of immunosuppression of spontaneous mammary tumorigenesis in mice. IRCS Med. Sci., 5, 219.

[8] 長澤 弘 (1978). 乳癌と prolactin receptor (綜説). 医 学のあゆみ, 105, 651-657.

[9] Nagasawa, H. (1979). Prolactin and human breast Cancer: A review. Europ. J. Cancer, 15, 267-279.

[10] Nagasawa, H. (1979). Causes of species differences in mammary tumourigenesis. Med. Hpoth., 5,499-510.

［11］長澤 弘（1979）. マウスにおける乳癌発生率と繁殖性の 関係. 第14回日本実験動物学会 (福岡).

[12] 長澤 弘・藤本政晴. 未発表.

[13] Nagasawa, H. and Kuretani, K. (1966). Influence of primiparous age and litter number on the time of mammary tumor appearance. Gann, 57, 491-496.

[14] Nagasawa, H. and Yanai, R. (1978). Normal and abnormal growth of the mammary gland. In Physiology of Mammary Glands. (Yokoyama, A., Mizuno, H. \& Nagasawa, H., editors), Jap. Sci. Soc. Press/ Univ. Park Press, Tokyo/Baltimore, 121-159.

[15] Nagasawa, H. and Yanai, R. (1978). Mammary gland prolactin receptor and pituitary prolactin secretion in lactating mice with different lactational performance. Acta endocrinol., 88, 94-98.

[16] 長澤 弘・矢内玲子, 未発表.

[17] Nagasawa, H., Fujimoto, M. and Kuretani, K. (1967). Normal growth and reproduction of a high and a low mammary tumor strains of mouse. Gann, 58, 115-123.

[18] Nagasawa, H., Fujimoto, M. and Kuretani, K. (1968). Further study on the influence of primiparous age and litter number on the mammary tumor age in mice. Gann, 59, 217-222.

[19］長澤 弘・小杉山基昭・榑谷和男(1971). 乳がんの発がん 性を指標としたスイスアルビノマウスの選抜と，それに伴 なら繁殖性㧍よび乳腺発育の変化. 実験動物. 19, 87-92.

[20] Nagasawa, H., Sakai, S. and Banerjee, M.R. (1979). Prolactin receptor (minireview). Life Sci., 24, 193208.

[21] Nagasawa, H., Tokuzen, R. and Nakahara, W. (1976). Growth of mammary tumors in a high and a low mammary tumor strains of mice established from the same basal stock of Swiss albino. Gann, 67, 913-915.

[22] Nagasawa, H., Yanai, R. and Azuma, I. (1978). Suppression by Nocardia rubra cell wall skeleton of mammary DNA synthesis, plasma prolactin level and spontaneous mammary tumorigenesis in mice. Cancer Res., 38, 2160-2162.

[23］長澤 弘・矢内玲子・宮本盛吉(1972). プロラクチンに対 するマウス乳腺の感受性におよぼす乳癌ウィルスの影簑. 日畜会報, 43, 519-523.

[24] Nagasawa, H., Yanai, R., Taniguchi, H. and Hayashi, S.(1979). Mammary tumour incidence in relation to the pattern of oestrous cycles in mice. Hormone Res., 10, 123-129. 
[25] Nagasawa, H., Yanai, R., Kosugiyama, M. and Fujimoto, M. (1969). Correlation between some characteristics as the indices of lactational performance of mouse. Jap. J. Zootech. Sci., 40, 61-66.

[26] Nagasawa, H., Morii,, S., Tsubura, A. and Yanai, R. (1977). Relative importance of genotype and type of mammary tumor virus on mammary tumorigenesis in mice. Europ. J. Cancer, 13, 1119-1222.

[27] Nagasawa, H., Yanai, R., Taniguchi, H., Tokuzen, R. and Nakahara, W. (1976). Two-way selection of Swiss albino mice for mammary tumorigenesis : Establishment of two new strains (SHN and SLN). J. Natl. Cancer Inst., 52, 425-430.

[28］中村玲子・徳永 徹 - 私信.

［29］中村玲子・徳永 徹・赤川清子・清水孝二・長澤 弘 (19 77). 乳癌高発系および低発系マウス(SHN および SLN) の免疫応答の比較. 第36回 日本癌学会総会記事 (東京).

[30] 日本実験動物研究会系統部会 (1973). マウウス近交系の公表 について (SHN). 実験動物, 22, 271-273.

[31] 日本実験動物研究会系統部会 (1975). マウス近交系の公表 につ、て (SLN). 実験動物, 24, 123-124.

[32] Sato, H., Kuroki, T., Narisawa, T., Fujii, K., Suzuki, M., Takahashi, T., Watanabe, K. and Goto, M. (1965). Characteristics of an inbred substrain $\left(\mathrm{C}_{3} \mathrm{H} /\right.$ $\mathrm{HeNSa}$ ) of $\mathrm{C}_{3} \mathrm{H}$ mouse, with reference to the mam- mary cancer incidence and metastasis. Gann, 56, 605-608.

[33] Sinha, Y. N., Salocks, C. B., VanderLaan, W. P. and Vlahakis, G. (1977). Evidence for an influence of mammary tumour virus on prolactin secretion in the mouse. J. Endocr., 74, 383-392.

[34] Staats, J. (1976). Standardized nomenclature for inbred strains of mice : Sixth Listing. Cancer Res., 36, 4333-4377.

[35] Tokuzen, R. (1971). Comparison of local cellular reaction to tumor grafts in mice treated with some plant polysaccharides. Cancer Res., 31, 1590-1593.

[36] Tokuzen, R., Kuretani, K. and Nakahara, W. (1974). Effect of cyclocytidine on spontaneous mammary adenocarcinoma of mice. Gann, 65, 89-91.

[37] Tsubura, Y., Imai, S., Hilgers, J. and Fine, D. L. (1978). Transmission of DD/Tbr mouse mammary tumor virus by maternal and paternal routes. 12th Int. Cancer Congr., Buenos Aires.

[38] Welsch, C. W. and Nagasawa, H. (1977). Prolactin and murine mammary tumorigenesis:A review. Cancer Res., 37, 951-963.

[39] 矢内玲子, 私信.

[40] 矢内玲子・長澤 弘・未発表 